\title{
Melanogaster ambiguus found in Finland
}

\author{
CARL-ADAM HÆGGSTRÖM
}

HÆGGSTRÖM, C.-A. 1981: Melanogaster ambiguus found in Finland. - Karstenia 21: $9-14$.

Melanogaster ambiguus (Vitt.) Tul. was found in 1977 in two localities in SW Finland. These are the first records of a Melanogaster species in Finland. The Finnish material is described, and the taxonomy of $M$. ambiguus and related species discussed. A description is given of the two localities and the total distribution of $M$. ambiguus is outlined.

Carl-Adam Haeggström, Department of Botany, University of Helsingfors, Unionsgatan 44, SF - 00170 Helsingfors 17, Finland

In 1977, during studies of the wooded meadows of Nåtö Nature Reserve on the Åland Islands, SW Finland, my attention was drawn to the fruit body of a hypogeous fungus protruding from the ground. Altogether nine fruit bodies were found in an area of about $0.5 \mathrm{~m}^{2}$. At first sight the fungus might be taken for a smooth Elaphomyces Nees ex Fr., but microscopic examination revealed that it is a basidiomycete. The brown peridium, the chambered gleba with the chamber walls visible as a whitish reticulum, and the dark spores, black in mass, are diagnostic of a species of the genus Melanogaster Corda, viz. M. ambiguus (Vitt.) Tul. I was not able to find other specimens of Melanogaster in Finnish herbaria (H, HFR, OULU, TUR and TURA, abbreviations of herbaria as in Holmgren \& Keuken 1974), but Dr. Harri Harmaja kindly placed at my disposal another collection from S. Finland. These are the first records of the genus Melanogaster in Finland. There is a collection in HFR labelled $M$. variegatus from N: Helsinki, Kallvik, 1950, leg. Ritva Ruotsalo, but in my opinion the two gastrocarps represent a species of Rhizopogon Fr.

\section{Materials and methods}

The collections examined by the author:

Finland. Alandia. Lemland, Nåtö, 30. VIII. 1977 Hæggström (H). - Regio aboensis. Lohja rural commune, Jalassaari, Tamminiemi, 15. VIII. 1977 Harmaja (H).

All the microscopic characters were observed on dry material in lactophenol. No significant reactions could be discerned in $1 \mathrm{~N} \mathrm{KOH}$ solution or in Melzer's reagent. From each gastrocarp examined 10-30 spores were measured. A series of four numbers is given in respect of the lengths and widths of the spores: minimal measurement - smallest mean value - greatest mean value - maximal measurement. Occasional giant spores have been excluded and the spore lengths do not include remnants of sterigmata. Whenever the characters differ in the two collections, they are given separately. The collections are referred to with the abbreviations: $\mathrm{N}=$ Nåtö, $\mathrm{T}=$ Tamminiemi.

The pH of two soil samples from Nåtö was determinated with a Beckman Electromate $\mathrm{pH}$ Meter; soil: aqua dest. c. 1:2.

The following description of Melanogaster ambiguus (Vitt.) Tul. is based on the Finnish material.

\section{Melanogaster ambiguus}

Gastrocarps subglobose to ellipsoid, some slightly lobed; size when fresh not noted, when dry deeply lobed with wrinkled surface, $5 \times 8-17 \times 22 \mathrm{~mm}$. Three dry halved gastrocarps (N) soaked in lukewarm water for two hours swelled up slightly (from $6 \times 12$ $\mathrm{mm}$ to $9 \times 15 \mathrm{~mm}$, from $9 \times 15 \mathrm{~mm}$ to $11 \times 17 \mathrm{~mm}$ and from $15 \times 19 \mathrm{~mm}$ to $17 \times 23 \mathrm{~mm}$ ). Surface with a few adpressed brown rhizomorphs, minutely felted with some soil particles adhering to it. Fresh gastrocarps heavy, somewhat spongy $(\mathrm{N})$, very hard when dry. Odour when fresh unpleasant or pungent, 


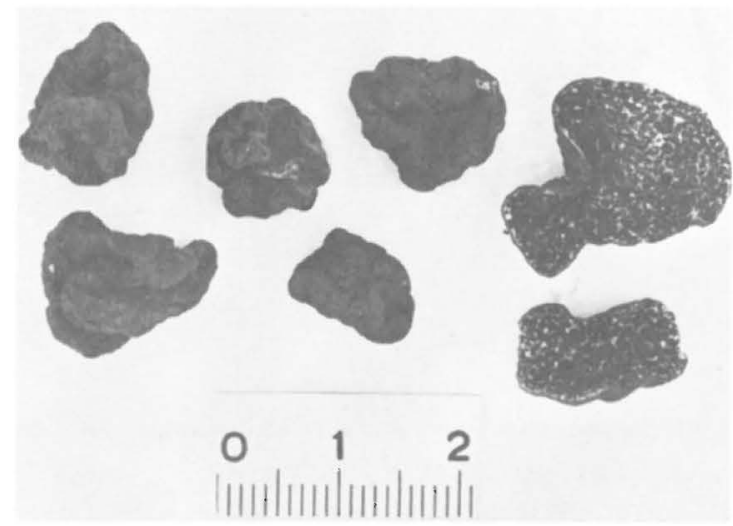

Fig. 1. Melanogaster ambiguus from Nåtö. In the two halved gastrocarps to the right, the gleba chambers and their whitish walls are clearly visible. - Photo Mauri Korhonen.

onion-like when dry $(\mathrm{T})$; faint, sweetish, resembling that of Gyromitra esculenta (Pers) Fr., especially in soaked gastrocarps $(\mathrm{N})$.

Peridium of dry gastrocarps brown - dull brown, $100-700 \mu \mathrm{m}$ thick. Surface layer consisting of 3.2-6.4 $\mu \mathrm{m}$ broad, loose, pale brown to almost hyaline hyphae, outer layer of 4.0-9.6 $\mu \mathrm{mr}$ broad, compact, yellowish-brown to reddish-brown hyphae, the hyphae becoming paler inwards, inner layer composed of $4.0-10.4 \mu \mathrm{m}$ broad, compact, hyaline hyphae.

Gleba chambered, black with whitish septa, fleshy or gelatinous in fresh $(\mathrm{N})$ and soaked gastrocarps. Septa $25-240 \mu \mathrm{m}$ broad. Chambers filled with a gelatinous and irregular mass of basidia, and spores. Basidia 3-4-spored $(\mathrm{T})$ or 4-spored $(\mathrm{N})$, hyaline, irregularly clavate to obtuse, $7-9 \mu \mathrm{m}$ broad near the apex, evanescent.

Spores (Fig. 2) when mature 12.0-14.9$16.2-21.6 \times 7.2-8.3-9.1-13.0 \mu \mathrm{m}$, often $(\mathrm{T})$ or usually $(\mathrm{N})$ citriform with a distinct papilla at the apex, often $(\mathrm{T})$ or occasionally $(\mathrm{N})$ obovoid with rounded apex, usually broadest at $(\mathrm{T})$ or above $(\mathrm{N})$ the middle, base truncate with a distinct remnant of the sterigma or only cup-chaped; wall yellowish when young, brown to dark brown when mature, thick, smooth. Contents occasionally uniguttulate, seldom biguttulate. Twin spores rare.

\section{Taxonomy}

The taxonomy of the genus Melanogaster is rather confused. The following characters have usually been considered reliable in distinguishing the species: size and shape of the gastrocarps, colour and thickness of the peridium, colour of the septa, colour, size and shape of the spores, and the odour of the fungus.

However, the size and shape of the gastrocarps usually vary too widely to be useful diagnostic characters (e.g. Hesse 1891, Soehner \& Knapp 1947, Knapp 1954). The colour of the peridium has often been regarded as a good character (Hesse 1891, Lange 1956, Schwärzel 1972, 1977), but as noted by some authors (e.g. Hesse 1891, Velenovský 1922, Soehner \& Knapp 1947, Knapp 1954) the colour differs with the stage of development, so that this character cannot be completely reliable, either. The thickness of the peridium may also be very variable (Soehner \& Knapp 1947).

The colour of the septa is not a constant character (e.g. Berkeley 1844, Soehner \& Knapp 1947, Knapp 1954) and the odour varies with the age of the gastrocarps (Berkeley 1844, Hesse 1891, Soehner \& Knapp 1947, Knapp 1954). The colour of the spores also varies according to the stage of maturity.

The most reliable characters appear to be the size and shape of the spores, but as has already been pointed out (e.g. by Soehner \& Knapp 1947), the size of the spores may vary considerably with the distance of the gleba chambers from the peridium. This variation is probably, at least partially, the reason for the overlapping in spore size in several of the taxa described.

The large spores (length more than $10 \mu \mathrm{m}$ ) of the Finnish specimens indicate that they belong to sect. Ambigui (Svrček 1958). Five species are usually considered to belong to this section, viz. Melanogaster ambiguus (Vitt.) Tul., M. intermedius (Berk.) Z. \& D., M. macrosporus Vel., M. rubescens (Vitt.) Tul. and $M$. tuberiformis Corda. In my opinion our specimens represent $M$. ambiguus. The spores are equal in size to those of $M$. ambiguus sensu Coker \& Couch (1928), Bottomley (1948), Knapp (1954), Lange (1956), Svrcek (1958), Trappe \& Guzmán (1971) and Benkert (1973). Smaller dimensions are given for the spores of $M$. ambiguus in Tulasne \& Tulasne (1851), Massee (1889), Hesse (1891), Velenovský (1922), Zeller \& Dodge (1937) and Hawker (1954). This may be due to the fact that spores of different degrees of maturity have been included. Further, the treatment of the material before the examination may affect the size of the spores. Only a few authors give an account of the treatment, e.g. Bottomley (1948), Hawker (1954), Lange (1956) and Trappe \& Guzmán (1971).

Vittadini (1831), who described $M$. ambiguus as Octaviania ambigua Vitt., gave no measurements of the spores, but stated that they are very large. According to Zeller \& Dodge (1937), the type is 
deposited in Broome Herb. at BM (now at $\mathrm{K}$, see Holmgren \& Keuken 1974). Lange (1956) was not able to locate the type in the collections of Vittadini in TO or in other herbaria.

According to information given by Dr. D.A. Reid at Kew (letter June 1980), there is nothing at $\mathrm{K}$ which corresponds with the specimen cited by Zeller \& Dodge (1937). One specimen at $\mathrm{K}$ is, however, labelled 'Octaviania ambigua Vitt., Hyperhiza liquaminosa Klot., saltem ex figuris et descriptione'. Dr. Reid reports that the label is written in the hand of Vittadini. The spores of this specimen are $12.4-16.8 \times 7.2-9.6 \mu \mathrm{m}$, mean $14.7 \times 8.6 \mu \mathrm{m}(\mathrm{n}=$ 20 ). They are papillate or obtuse. In my opinion this specimen represents $M$. ambiguus and may be the type.

Vittadini (1831: Pl. IV, Fig. VIIb) depicts the spores of Octaviania ambigua as apparently papillate.
The spores of $M$. ambiguus are also seen to be papillate in the illustrations of Tulasne \& Tulasne (1843), Massee (1889), Coker \& Couch (1928), Hawker (1954), Knapp (1954), Lange (1956), Svrček (1958), Schwärzel (1977) and de Vries (1979). In a scanning electron micrograph of spores of $M$. ambiguus in Hawker (1975), the shape of the apices of the spores is unfortunately not clearly visible, Most of the authors cited above, and Benkert (1973) as well, mention that the spores are papillate, but Lange (1956:62) writes: 'The papillate spores are not constant enough in occurrence to be regarded as a stable character'. In my opinion, the papillate spores seem to be a good character of $M$. ambiguus.

$M$. intermedius was described as $M$. ambiguus $\beta$ intermedius by Berkeley (1844), though he thought that it is probably a separate species. His description was based on an imperfect specimen. He writes as
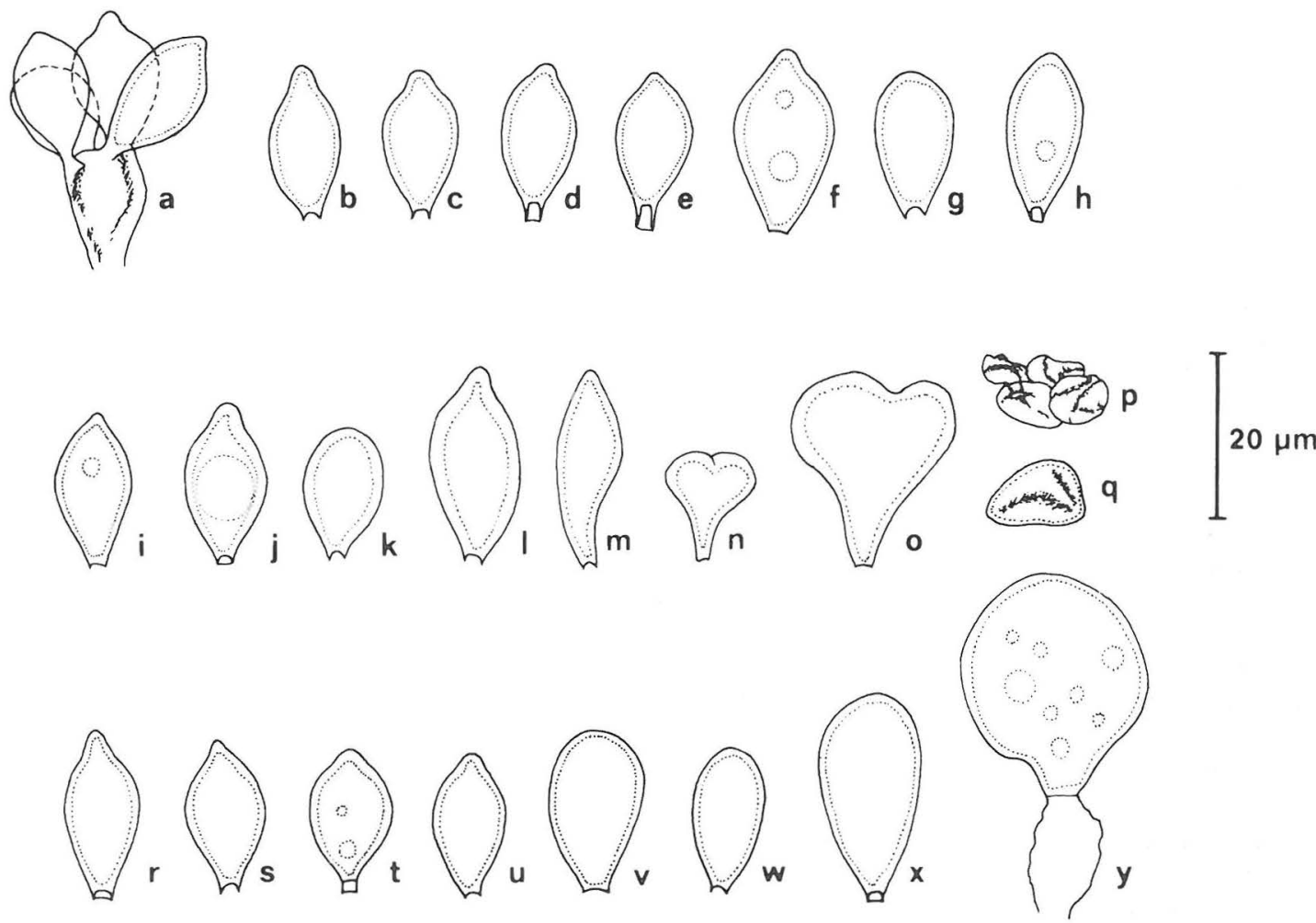

Fig. 2. Spores of Melanogaster ambiguus: a-h) from largest halved gastrocarp from Nåtö, i-q) from smallest halved gastrocarp from Nåtö, $r-y$ ) from small gastrocarp from Tamminiemi. Drawn with the aid of a camera lucida from dry material in lactophenol. - a) Basidium with four almost ripe spores. - b-f) Papillate spores (b-c with cup-shaped base, d-e with remnants of sterigmata, f large spore, biguttulate). - g-h) Spores with rounded apices (h uniguttulate). - i-j) Papillate, uniguttulate spores. - k) Spore with rounded apex. - l-m) Giant spores (m somewhat abnormal). - n-o) Twin spores. - p) Four abortive spores. - q) Abortive spore. - r-u) Papillate spores (t biguttulate). — v-x) Spores with rounded apices ( $\mathrm{x}$ giant spore). $-\mathrm{y}$ ) Basidium with single abnormal, octoguttulate giant spore. 
follows of the spores of $M$. ambiguus $\beta$ intermedius: ...'equalling in size those of $M$. ambiguus, though of a very different form. There is scarcely ever the slightest inication of a papilla, and they are obovate with a single globose nucleus' (Berkeley 1844: 354-355). Berkeley gave no spore dimensions.

Zeller \& Dodge (1937) raised $M$. ambiguus var. intermedius to the rank of species. According to them, and to Knapp (1954) and Svrček (1958), its spores are slightly smaller than those of $M$. ambiguus. Lange (1956) is of the opinion that $M$. intermedius is evidently synonymous with $M$. macrosporus, because both Massee (1889) and Hawker (1954) found that the type had spores as large as those of $M$. ambiguus. However, Massee (1889) was obviously only quoting Berkeley (1844), since his text is exactly the same as that author's, apart from some differences in punctuation, and Hawker's (1954) measurements of the spores of $M$. intermedius are actually larger than those of her $M$. ambiguus.

Zeller \& Dodge (1937) reported that the type of $M$. intermedius is preserved in Herb. Broome at BM (now transferred to $\mathrm{K}$ ) and Herb. Tulasne at PC. The only specimen of $M$. ambiguus var. intermedius known to be preserved at K (Dr. D.A. Reid, letter June 1980) is labelled 'Spye Park, 1845, ex Herb. Broome', but as the type was collected in August 1843, this cannot be the type. The spores of this specimen are obtuse or very slightly papillate, and unripe. They are 9.6-12.8 $\times 5.2 \times 7.2 \mu \mathrm{m}$, mean $11.3 \times 6.4 \mu \mathrm{m}(\mathrm{n}=20)$.

Another specimen at $\mathrm{K}$ is labelled 'Octaviania ambigua Vitt., Spye Park, Aug. 1843, ex Herb. Broome'. The spores are palish, and brown in mass. Further, they are obtuse and fairly small: 9.6-13.6 $\times 6.0-7.2 \mu \mathrm{m}$, mean $11.3 \times 6.6 \mu \mathrm{m}(\mathrm{n}=25)$. In my opinion this specimen represents $M$. tuberiformis.

According to Dr. J. Mouchacca, Paris (letter October 1980), there is no type of $M$. intermedius at PC.

$M$. macrosporus was described by Velenovský (1922, Latin diagnosis in Pilát 1948). According to the description, the spores are obovoid-ellipsoid, narrower at the base, which is truncate, contain 3-4 small bodies, and are blackish brown, smooth, 15-18 $\mu \mathrm{m}$ (Velenovsky 1922). The width of the spores is not given. The location of the type is unknown. It is not deposited at PRM or PRC (Dr. Z. Pouzar and Dr. Z. Urban, Prague, letters April and May 1980).

Judging from the text and figures in Knapp (1954), Lange (1956) and Svrcek (1958), the spores of $M$. ambiguus and $M$. macrosporus are almost equal in size and of nearly the same shape. According to
Knapp (1954) and Svrček (1958), the spores of $M$. macrosporus are more slender than those of $M$. ambiguus. The spores of $M$. macrosporus usually lack the papilla at the apex, but papillate spores are occasionally found (Knapp 1954, Lange 1956, Svrček 1958). According to Lange (1956), the best character distinguishing $M$. macrosporus from $M$. ambiguus is the rich dark brown colour of the peridium, and further the larger size of the gastrocarps, narrow septa, thin peridium and sweetish odour in $M$. macrosporus. M. ambiguus is distinguished from the other large-spored species by its small size and the dull colour of the peridium (Lange 1956). Thus the two species can be distinguished only on the base of characters that are considered unreliable by Hesse (1891), Soehner \& Knapp (1947) and Knapp (1954), Velenovský (1922) himself described the colour of the peridium of $M$. macrosporus as brown in young and dark chestnut-brown in older gastrocarps, i.e. the colour is not a constant character in this species.

$M$. rubescens and $M$. tuberiformis differ from the present specimens in having smaller, non-papillate spores. Furthermore, the spores of $M$. rubescens are slender and pale (Zeller \& Dodge 1937, Knapp 1954, Lange 1956, Svrček 1958 and Szemere 1965).

If only the spores are considered, it is obvious that overlapping exists between $M$. ambiguus, $M$. intermedius and M. macrosporus, and perhaps also $M$. tuberiformis. As the types are lacking it is difficult to determine whether $M$. intermedius and $M$. macrosporus are separate species or not. The easiest way to solve this problem would be to unite these four taxa in one single species, $M$. ambiguus, as has been suggested by Szemere (1965).

\section{Ecology and distribution}

Both the Finnish localities of $M$. ambiguus are situated in the hemiboreal zone (cf. Ahti et al. 1968). The Nåtö locality is a restored wooded meadow belonging to the Nature Reserve. The gastrocarps were found in the bare humified basal part of an anthill (Formica rufa coll.). Of the nine gastrocarps, only one was partially exposed, the other eight were growing in the earth at a depth of $\mathrm{c} .1-2 \mathrm{~cm}$. The vegetation is luxuriant (cf. Stenlid 1961). The main tree and shrub species in the habitat are Corylus avellana (very abundant), Alnus glutinosa, Ulmus glabra, Acer platanoides, Fraxinus excelsior and Viburnum opulus (vascular plant nomenclature according to Hämet-Ahti et al. 1980). Picea abies was previously abundant, but in 1962 when the wooded meadow was partly restored, almost every spruce was felled (Hæggström 1976a, 1876b). Three large 
spruce trees were left in the vicinity of the anthill, but they were cut down in 1968. The area has been grazed by sheep in 1965-66 and 1969-72, and by cattle since 1974 (cf. Hæggström 1976a).

The field layer is rich in species, many of which have a south-western distribution in Finland. Typical spring-flowering species are Hepatica nobilis, Anemone nemorosa, Primula veris, Adoxa moschatellina, Lathraea squamaria, Gagea lutea, Paris quadrifolia, Luzula pilosa and Carex digitata. Other species here are Rubus saxatilis, Trifolium medium, Heracleum sphondylium ssp. sibiricum, Laserpitium latifolium, Viola mirabilis, Dentaria bulbifera, Melampyrum sylvaticum, Poa nemoralis, Dactylis glomerata and Milium effusum.

The humus layer consists of circumneutral mull. However, the $\mathrm{pH}$ of the humus in which $M$. ambiguus was found is rather low: 5.55 and 5.70, obviously due to the fact that the parent material of the basal part of the anthill was mainly spruce needles. The mineral soil is stony till. It is rich in calcium due to postglacial deposits of Ordovician limestone (cf. Brenner 1930).

The island of Nåtö is known for its rich flora of fungi. Many exacting species with a southern distribution in Finland have been found here, e.g. Amanita phalloides (Fr.) Secr., Gyrodon lividus (Fr.) Sacc., Boletus chrysenteron Bull. ex St-Amans, $B$. porosporus (Imler) Watl., B. erythropus (Fr.) Krombh., B. luridus Schaeff. ex Fr., Spongipellis spumeus (Fr.) Pat. and Phallus impudicus Pers. (cf. Stenlid 1947, Kallio \& Heikkilä 1978). Melanogaster ambiguus evidently belongs to this group of southern species whose distribution extends into the northern parts of the hemiboreal zone.

The locality at Tamminiemi is a park-like open grass-herb forest with indigenous broad-leaved trees: Quercus robur, Betula pendula, Acer platanoides, Populus tremula, Salix caprea, Tilia cordata, and the shrub Corylus avellana. Foreign conifers (?Pseudotsuga menziesii (Mirb.) Franco) were growing $15 \mathrm{~m}$ away from $M$. ambiguus. The soil is fairly calcareous and the habitat is moderately influenced by man. The two gastrocarps were halfburied in bare clayey mull soil. Other fungi in the vicinity included Boletus reticulatus Boud. and Tricholoma sulphureum (Fr.) Kumm.

$M$. ambiguus s.str, has been found in deciduous woodlands in Western and Central Europe, especially in beech, oak and hornbeam woods (e.g. Vittadini 1831, Tulasne \& Tulasne 1843, 1851, Hesse 1891, Zeller \& Dodge 1937, Hawker 1954, Knapp 1954, Lange 1956, Svrček 1958). The gastrocarps have been found at all times of the year, but mainly in April to
October (Hesse 1891, Zeller \& Dodge 1937, Hawker 1954, Lange 1956, Svrček 1958).

M. ambiguus s.str, has a wide total distribution. It has been reported from several parts of Europe: from England and France in the west to the vicinity of Moscow in Russia in the east, and from Italy in the south to Denmark and southern Sweden in the north (Vittadini 1831, Tulasne \& Tulasne 1843, 1851, Berkeley 1844, Hesse 1891, Bucholtz 1901, T.M. Fries 1909, T.C.E. Fries 1921, Velenovský 1922, Hawker 1954, 1974, Knapp 1954, Lange 1956, Svrček 1958, Schwärzel 1972, Benkert 1973 and de Vries 1979). The records in Finland are the northernmost so far made in Europe. In addition, M. ambiguus has been reported from the U.S.A. (Coker \& Couch 1928, Zeller \& Dodge 1937), Mexico (Trappe \& Guzmán 1971), South Africa (Bottomley 1948), India and New Zealand (Svř̌ek 1958).

Acknowledgements. I wish to thank Dr. F. Kotlaba (Prague) for help with the translation of the Czech description of $M$. macrosporus, Dr. D.A. Reid (Kew) for valuable information on some specimens on loan from $K$, Dr. Z. Pouzar and Dr. Z. Urban (Prague) for help in searching for the type of $M$. macrosporus, and Dr., J. Mouchacca (Paris) for help in searching for the type of $M$. intermedius. I am indebted to Dr. H. Harmaja for valuable comments on the manuscript and for placing at my disposal the gastrocarps from Tamminiemi. Further, I am indebted to Prof. T. Ahti and Dr. T. Niemelä, who read the manuscript and made valuable suggestions. Mr. M. Korhonen took the excellent photograph. Mrs. Anna A. Damström, M.A., kindly corrected the English text of the manuscript.

\section{References}

A hti, T., Hämet-A hti, L. \& Jalas, J. 1968: Vegetation zones and their sections in northwestern Europe. - Ann. Bot. Fennici 5: 169-211.

Benkert, D. 1973: Über Neufunde seltener Gasteromyceten in Brandenburg. - Gleditschia 1: 113-121.

Berkeley, M.J. 1844: Notices of British fungi. - Ann. Mag. Nat. Hist. 13: 340-360.

Bottomley, A.M. 1948: Gasteromycetes of South Africa. Bothalia 4: 473-810.

Brenner, W. 1930: Beiträge zur edaphischen Ökologie der Vegetation Finnlands 1. Kalkbegünstigte Moore, Wiesen und Wiesenwälder. - Acta Bot. Fennica 7: $1-97$.

Bucholtz, F. 1901: Hypogaeen aus Russland. - Hedwigia 40: $304-322$.

Coker, W.C. \& Couch, J.N. 1928: The Gasteromycetes of the eastern United States and Canada. - 201 pp., 123 pls. Chapel Hill, N.C.

Fries, T.C.E. 1921: Sveriges Gasteromyceter. - Arkiv Bot. 17(9): $1-63$.

Fries, T.M. 1909: Skandinaviens tryfflar och tryffelliknande svampar. - Svensk Bot. Tidskr. 3: $223-300$.

Hawker, L.E. 1954: British hypogeous fungi. - Philosoph. Trans. R. Soc. London, Ser. B, 237: 429-546. 
Hawker, L.E. 1974: Revised annotated list of British hypogeous fungi. - Trans. Brit. Mycol. Soc. 63: $67-76$.

- 1975: Scanning electron microscopy of basidiospores as an indication of relationships among hypogeous Gasteromycetes. - Nova Hedwigia, Beih. 51: $123-132$, pls. $31-35$.

Hesse, R. 1891: Die Hypogaeen Deutschlands 1. Die Hymenogastreen. - 133 pp., 11 pls. Halle a. S.

Holmgren, P.K. \& Keuken, W. 1974: Index Herbariorum 1. The herbaria of the world. 6th ed. - Regnum Vegetabile 92: 1-397.

Hrggström, C.-A. 1976a: Problem i samband med igenväxande löväng på Åland (Preliminär rapport). Gjengroing av kulturmark. Internordisk symposium 27-28 nov. 1975, Norges Landbrukshøgskole, Ås. 11 pp.

- 1976b: Lövängsvård - också hos oss. (Summary: Restoration of wooded meadows in Finland.) Dendrol. Seuran Tiedotuksia/Dendrol. Sällsk. Not. 7: $35-41$.

Hämet-Ahti. L., Jalas, J. \& Ulvinen, T. 1980: Suomen alkuperäiset ja vakiintuneet putkilokasvit. 2nd ed. Helsingin Yliopiston Kasvitieteen Laitoksen Monisteita 61: $1-111$.

Kallio, P. \& Heikkilä, H. 1978: The boletes of Finland 1. Genus Boletus. - Karstenia 18: 1-19.

Knapp, A. 1954: Die europäischen Hypogaeen-Gattungen und ihre Gattungstypen 2. - Schweiz. Z. Pilzkunde 32: $33-44,117-130,149-155$.

Lange, M. 1956: Danish hypogeous macromycetes. Dansk Bot. Arkiv 16(1): 1-84.

Massee, G. 1889: A monograph of the British Gastromycetes. - Ann. Bot. 4: 1-103, pls. 1-4.

Pilát, A. 1948: Velenovskýi species novae Basidiomycetum quas in opere 'Ceské houby' (Fungi Bohemiae), annis $1920-22$ in lingua bohemica edito, descripsit. - Opera Bot. Čechica 6: 1-301.
Schwärzel, C. 1972: Beitrag zur Hypogaeenflora des Kantons Basel-Stadt und seiner näheren Umgebung (Fortsetzung). - Schweiz. Z. Pilzkunde 50: 15-19, $61-67$.

- 1977: Beitrag zur Hypogaeenflora des Kantons BaselStadt und seiner näheren Umgebung (Fortsetzung). Schweiz. Z. Pilzkunde 55: $145-155$.

Soehner, [E.] \& Knapp, [A.] 1947: Melanogaster-Studie. Schweiz. Z. Pilzkunde 25: 149-156.

Stenlid, G. 1947: Några anteckningar om Ålands svampflora. - Memoranda Soc. Fauna Flora Fennica 23: $82-90$.

- 1961: Nåtö - ett nytt naturskyddsområde på Åland. Finlands Nat. 19: 4-10.

Svrček, M. 1958: Melanogastrales - Černouškotvaré. In: Pilát, A. (ed.), Flora ČSR, B1, Gasteromycetes: 527-556, 795-802. Praha.

Szemere, L. 1965: Die unterirdischen Pilze des Karpatenbeckens. - 319 pp., 10 pls. Budapest.

Trappe, J.M. \& Guzmán, G. 1971: Notes on some hypogeous fungi from Mexico. - Mycologia 63: $317-332$.

Tulasne, L.-R. \& Tulasne, C. 1843: Champingnons hypogés de la famille des Lycoperdacees, observés dans les environs de Paris et les départements de la Vienne et d'Indre-et-Loire. - Ann. Sci Nat., Ser. 2 Bot. 19: 373-381, pl. 17.

- 1851: Fungi hypogæi. Histoire et monographie es champignons hypoges. - 222 pp., 21 pls. Parisiis.

Velenorský, J. 1922. Ceské houby 4-5. - Pp. 633-950. Praha.

Vittadini, C. 1831: Monographia Tuberacearum. - 88 pp., 5 pls, Mediolani.

de Vries, G.A. 1979: Bijdrage tot de kennis van de Nederlandse Hypogaea. - Coolia 22: 2-12.

Zeller, S.M. \& Dodge, C.W. 1937: Melanogaster. - Ann. Missouri Bot. Garden 23: 639-655. 